\title{
Review on the Study of the Allocation of Corporate Control in Enterprise Theory
}

\author{
ZHOU Jun, MING Da-zeng, OU Xu-dong \\ Wuhan University of Technology, Wuhan, China
}

\begin{abstract}
With the establishment of a modern corporate system, the separation of ownership and management appears in the company. The rational allocation of corporate control between different behavioral agents has attracted more and more attention. This paper points out that scholars have studied the allocation of corporate control from the angles of the agency cost theory, property rights theory, corporate finance theory, and the theory of corporate governance, which has great value. However, the existing theories also have some flaws on the allocation of corporate control. First, people still have different understandings and views over the meaning of corporate control. Secondly, the existing research theoretically only observes and studies an arrangement of sheer level control, the allocation between final control and real control. This paper argues to build the two-tier allocation of corporate control: The first tier relation is between ultimate control rights and actual control rights, the second tier relation is between indirect control rights and direct control rights which are in actual control rights. This study can explain the resource allocation effects of corporate control, promote the development and improvement of the theory of the firm.
\end{abstract}

Keywords: corporate control, allocation of rights, corporate governance

\section{Introduction}

The arrangement and exercise of corporate control are directly related to the status of corporate governance and the efficiency of corporate resource allocation. Corporate control is a core concept to understand the enterprise system. So far, in academia, there are still different views about the definition of corporate control. We believe that in essence, corporate control is the right of resource allocation, which is the power of integrating the corporate resources and coordinating the corporate operation.

In modern corporations characterized by the separation of ownership and control, in essence, corporate control is the right of resource allocation. In modern corporations, the corporate control is owned or mastered by different behavioral agents. And these behavioral agents interact and restrict each other, forming various allocation mechanisms of control rights. Countries have formed a variety of distinctive allocation mechanisms of corporate control in the course of long-term development, which have solved many problems in corporate governance. From the practice of corporate governance of all countries, however, the efficient allocation of

ZHOU Jun, Ph.D., Professor, Ph.D. Supervisor, School of Economic, Wuhan University of Technology.

MING Da-zeng, Ph.D. Candidate, School of Economic, Wuhan University of Technology.

OU Xu-dong, Master Candidate, School of Economic, Wuhan University of Technology.

Correspondence concerning this article should be addressed to ZHOU Jun, No. 122 Luoshi Road, Wuhan, 430070, China. E-mail: zhoujun601@sina.com. 
corporate control among different behavioral agents has not got an effective solution. For a long time, some scholars of the enterprise theory have done a lot of exploration of the allocation mechanism of control rights and achieved many theoretical results. In this paper, centered on the allocation mechanism of corporate control, the related theories are summarized and reviewed briefly.

\section{Allocation of Control Rights in the Agency Cost Theory}

Scholars who hold the agency cost theory believe that it is impossible for shareholders as the principal at zero cost to ensure that the agent will make optimal decisions from the principal's viewpoint because of the agency costs, including the monitoring expenditures by the principal, the bonding expenditures by the agent, and the residual loss caused by the divergence between the agent's decisions and those decisions which would maximize the welfare of the principal. In the agency cost theory, the best allocation of control rights should minimize these agent costs.

Earlier literatures of agency cost theory emphasized the arrangement of control rights between shareholders and managers, forming an allocation relationship between shareholders and managers. As representatives of agency cost theory, Fama and Jensen have conducted some analysis on it. Fama and Jensen (1983) examined the problem of decision-making management and decision-making control in a public company. In accordance with the decision-making process, they divided corporate decisions into decision-making management and decision-making control. Decision-making management refers to the proposals of the initial decision-making program and the implementation of the approved program plan, and decision-making control includes the rights to make final decisions and supervise the program upon approval. In order to reduce agency costs, they believe that the rights of decision-making management should be allocated to the managers and the owners should have the rights of decision-making control.

In modern corporations, directly to supervise and constrain the management is mainly by the board of directors. So there has formed an allocation relationship of control rights between the board of directors and management. Fama (1980) emphasized the board's important role in reducing agency costs. He believed that the board of directors is a supreme internal supervisor in the enterprise contract and its most important function is to supervise internal top decision-makers. The role of the board of directors is to provide a replacement mechanism which costs relatively lower than the outsider when replacing or adjusting the senior managers. Jensen and Ruback (1983) have conducted some analysis on the role of the board of directors. They thought it as a management team, board of directors has the rights to hire, fire, and set the top managers' compensation. In their view, top managers are responsible for the management activities of a specific resource. They master the right to select managers and so hold the real control right of the company.

Although they possess the mission of constraining management of legal provisions, actually the board of directors often cannot fulfill this responsibility. Some scholars have discussed this issue. Patton and Baker (1987) believed as the CEO plays an important role in terms of designing and leading the board, the board of directors has been the puppet of CEO for a long time. Because of this, Salmon (2000) put forward to improve the efficiency of the board of directors and strengthen the power of the board of directors relative to the CEO. For example, we should limit to expand the scale of the board of directors, increase the quantity of outside directors, transform the function of the committees of the board, etc..

Of course, as the agent of shareholders, board of directors will also be supervised and constrained by shareholders or shareholders' meeting. So there exists an allocation problem of corporate control between the 
shareholders and the board of directors. Currently scholars also emphasize the balance of the general meeting of shareholders relative to the board of directors. For example, Becht, Franks, Mayer, and Rossi (2009) thought shareholder's rights should include voting rights of shareholders. The voting right is an important tool for the election of directors, as well as the approval of the annual report and budget. Ertimur, Ferri, and Stubben (2010) thought even if the vote of the shareholders at the shareholders' meeting has no legal binding, the resolutions that win the most votes in many cases finally need implementing by the board of directors.

\section{Allocation of Control Rights in Incomplete Contract and Property Right Theory}

Incomplete contract and property right theory founded by Hart et al. is an important branch of enterprise theory. In their view control rights are derived from the incompleteness of the contract. Hart (1995) thought it necessary to solve the problem caused by insufficient incentive of investment in advance due to incomplete contract through appropriate allocation of residual control.

Given the purchase contract ordered when firm 1 buys firm 2 as an example, Grossman and Hart (1986) put forward these two concepts of the specific rights of control and the residual rights of control. They called all the specific rights of assets listed in the contract the specific rights of control and believed the rights owned by firm 2's original owner as a manager of a new subsidiary belong to this situation after firm 1 purchases firm 2 . And the rights which are not listed in the contract all refer to the residual rights of control. They thought it is the power which cannot be clearly defined in advance. They regarded the residual rights of control as ownership and think the party who has important investment should have the residual rights of control. Grossman and Hart (1986) also clearly put forward that the residual control is the rights to decide all usages of the assets that have not been given away by previous contracts, conventions, or laws.

Hart and Moore (1990) further analyzed the nature and ownership of the residual rights of control. They suggested that the distribution of future earnings of the party's current action depends on his negotiating position. And the negotiating position is highly associated with the distribution of the ownership of assets. Therefore the allocation of current asset ownership determines future earnings of the party's current action, which is directly related to the efficiency of the current action. So the ownership of the asset should be allocated to the indispensable party. They also point out that a unique right of an asset that the owners have is its ability to reject others to use the asset. The control of a physical asset could indirectly lead to the control of human assets. Hart (1995) has clearly put forward when other condition is constant, the party who has important investment should have such control rights and highly complementary assets should be put under common ownership.

The theory above established by Hart et al., based on incomplete contract, is usually called incomplete contracting theory (GHM model). This theory only applies to the classical enterprise without the constraint of wealth. It is worth noting that in the recent literature Hart has discussed the allocation problems of modern corporate control, thus expanded the early GHM model. Different from only emphasizing on the owners of material assets who have the right to make decisions, Hart (2011) pointed out that in most large organizations, legal control rights are conferred to the board of directors rather than the owner of shareholders or the general meeting of shareholders and board of directors always has legal rights of making decisions at some point. Hart and Holmstrom (2010) divided control rights in the modern company into formal control and real control. They pointed out the arrangement of the control rights can reach a compromise between complete centralization and full decentralization, forming a good allocation framework of control rights between the boss and the subordinate. 


\section{Allocation of Control Rights in the Corporate Finance Theory}

A corporate finance theory is a new theory over the past 20 years. This theory stresses that with the separation of corporate ownership and control rights, financing mode and the financial structure have important effects on the allocation of control rights. Its representative figures are Aghion and Tirole, etc..

Aghion and Bolton (1992) took control as a right of decision-making and on the assumption of the limited wealth, analyzed the arrangement and the transfer of the control rights between investors and entrepreneurs. Aghion and Tirole (1997) distinguished the formal and real control, and thought the formal control is the right to make decisions and real control is the effective control of decisions. They compared the gain and loss when delegating the formal control rights to the agents: On the one hand, it will facilitate the agent's participation in the organization and also will foster his incentive to acquire relevant information. On the other hand, the delegation may make the principal lose control of the decisions, leading to losses. So the allocation of the formal control should be determined by the nature of the decisions. If this decision is relatively unimportant for the principal, or the principal can trust the agent, or it is important for the agent, or the principal has not accumulated the competency of the decision-making, the formal authority should be delegated to the agent.

Based on his assumption on the fact that entrepreneurs' personal wealth is insufficient, which needs to introduce outside investment, Tirole (2001) analyzed the allocation of control rights between investors and entrepreneurs. He pointed out that there are two conditions to allocate the control to investors: to improve the value of the enterprise and increase the pledgeable income. If the two conditions above are met, control of investors is first-best optimal; otherwise, the control should be held by entrepreneurs. On the basis that control rights in the modern company were divided into formal and real control, Tirole also made a more detailed investigation of the agent of real control. He pointed out that the management is able to make some important decisions such as long-term investment, dividends and retained earnings and new debt and other security issues, the CEO's successor, and takeover defenses. Because management has information superiority, and they are able to have a significant impact on decisions, and often hold the real control rights. One important duty of the board of directors is to supervise pension funds, mutual funds, a venture capital, Leveraged Buyout (LBO), or bank business in order to change the way they act and thereby make it more efficient. The real control that managers have is not absolute due to the important effects of the board of directors of company operation. Tirole also pointed out that the formal control is held in the hands of investors, especially the shareholders in the company. In Tirole's view, the management is more constrained by investors especially shareholders in the company. Security incentive based on accounting data and stock option incentive based on market indicators will encourage management to act in the interests of the shareholders.

\section{Allocation of Control Rights in the Corporate Governance Theory}

Allocation of control rights involves the respective functions and the mutual relationship of the general meeting of shareholders, board of directors, board of supervisors and management, which is an important issue that corporate governance theory focuses on and discusses.

According to the Organization for Economic Cooperation and Development (OECD, 2004), shareholders have the rights to attend the shareholders meeting, vote and remove members of the board of directors as well as the right to share the profits; board of directors has the right to appoint and remove the company's management, and supervise and motivate the managers through appointing independent directors, formulating 
management remuneration, and setting up the audit committee and nomination committee, remuneration and appraisal committee; board of supervisors is the company's permanent supervision organization under the leadership of shareholders' general meeting, responsible for the general meeting of shareholders and independently exercises the right of supervision to the board of directors, management, and the whole company.

\section{Review}

As can be seen from the above, scholars have done a lot of research and made many achievements on the arrangement, balance, and other issues of corporate control. In fact, some research findings in this field are high-profile. The research on control allocation between the principal and the agent in agent cost theory and the analysis of the nature and the distribution of the residual control in the incomplete contract and property right theory, and some of them have become classical enterprise theories. The division of ultimate control and real control in corporate finance theory and the research on the agents of control rights and the relationship among them in corporate governance theory also has very vital significance in the study of the corporate control allocation.

However, the existing theories also have some flaws on allocation of corporate control. First, people still have different understandings and views over the meaning of corporate control. For example, people who hold the agency cost theory generally regard corporate control as "management", and in the incomplete contract and property right theory and corporate finance theory, people often regard the control as "decision-making" of the usages of company assets, in the corporate governance theory people believed it was a kind of "influence" on corporate behavior process. This divergence can lead to a variety of ambiguity or confusion in the study. In fact, if you consider the nature of corporate control as a right of resource allocation, then the "management", "decisions", and "influence" are its concrete forms. Reviewing the allocation mechanism of corporate control on this basis will help to deepen the understanding of the problem.

Secondly, the existing research theoretically only observes and studies an arrangement of sheer level control, the allocation between final control and real control. Although Jensen and Ruback (1983) and Tirole (2001) regarded management and the board as the owner of the real control, they have not further subdivided real control. It is not conducive to a specific research on the allocation mechanism for corporate control. Theoretically, effective control rights of the company can be further subdivided into indirect control and direct control. Indirect control of the board of directors and board of supervisors exercises in the way of collective decision-making, this power is not involved in the day-to-day resource allocation; and direct control by the management mainly based on individual decisions is engaged in the daily allocation of corporate resources. Building corporate control theory model of double deck arrangement is conducive to more in-depth research for the allocation of corporate control. However, this research is absence.

\section{References}

Aghion, P., \& Bolton, P. (1992). An incomplete contracts approach to financial contracting. Review of Economic Studies, 59, 473-494.

Aghion, P., \& Tirole, J. (1997). Formal and real authority in organization. Journal of Political Economy, 105(1), 1-29.

Becht, M., Franks, J., Mayer, C., \& Rossi, S. (2009). Returns to shareholder activism: Evidence from a clinical study of the Hermes UK focus fund. Review of Financial Studies, 22(8), 3093-3129. 
Ertimur, S. Y., Ferri, F., \& Stubben, S. R. (2010). Board of directors' responsiveness to shareholders: Evidence from shareholder proposals. Journal of Corporate Finance, 16(1), 53-72.

Fama, E. F. (1980). Agency problem and the theory of the firm. Journal of Political Economy, 88, 288-307.

Fama, E. F., \& Jensen, M. C. (1983). Separation of ownership and control. Journal of Law and Economics, 26, 301-325.

Grossman, S. J., \& Hart, O. D. (1986). The costs and benefits of ownership: A theory of vertical and lateral integration. Journal of Political Economy, 94(4), 691-719.

Hart, O. D. (1995). Firms, contracts and financial structure. Oxford: Oxford University Press.

Hart, O. D. (2011). Thinking about the firm: A review of Daniel Spulber's the theory of the firm. Journal of Economic Literature, 49(1), 101-113.

Hart, O. D., \& Holmstrom, B. (2010). A theory of firm scope. Quarterly Journal of Economics, 125(2), 483-513.

Hart, O. D., \& Moore, J. (1990). Property rights and the nature of the firm. Journal of Political Economy, 98(6), 1119-1158.

Jensen, M. C., \& Ruback, R. S. (1983). The market for corporate control: The scientific evidence. Journal of Financial Economic, $11,5-50$.

Organization for Economic Cooperation and Development (OECD). (2004). OECD principler of corporate governance. Paris: OECD Publications.

Patton, A., \& Baker, J. C. (1987). Why do not directors rock the boat. Harvard Business Review, 656, 10-12.

Salmon, W. J. (2000). Corporate governance. Boston: Harvard Business School Press.

Tirole, J. (2001). Corporate governance. Econometrica, 69(1), 1-35. 